\title{
Pectate Lyase Promoting Streptolysin O Expression in Escherichia coli and Strengthening Its Activity
}

\author{
Zhao Qingxin, ${ }^{1,}{ }^{*}$ He Jing, ${ }^{2}$ Ye Kaixia,,3 Wang Jian, ${ }^{1}$ Kang Yijun, ${ }^{1}$ Shen Min, ${ }^{1}$ and Wang Huanli ${ }^{1}$ \\ ${ }^{1}$ Jiangshu Key Laboratory for Bioresources of Saline Solis, Yancheng Teachers University, Yancheng, People's Republic of China \\ ${ }^{2}$ Neurology Department, Qianfoshan Hospital of Shandong Province, People's Republic of China \\ ${ }^{3}$ College of Food Science and Light Industry, Nanjing Tech University, Nanjing, People's Republic of China \\ "Corresponding author: Zhao Qingxin, Jiangshu, Key Laboratory for Bioresources of Saline Solis, Yancheng Teachers University, Yancheng, People's Republic of China. E-mail: \\ 450170029@qq.com
}

Received 2017 February 27; Revised 2017 May 31; Accepted 2017 June 24.

\begin{abstract}
Background: Streptolysin O (SLO) from Streptococcus pyogenes could oligomerize to form large pores on the membrane of some eukaryotic cells. Because of the action, SLO had multifaceted applications in animal cell biology and medicine science. In the previous researches, the highest yield of recombinant expressed SLO might be no more than $124 \mathrm{mg} / \mathrm{L}$ medium.

Objectives: A fusion protein of pectate lyase and streptolysin O (PEL-SLO) was highly expressed with the pectate lyase (PEL, from Aspergillus nidulans) as fusion partner. The expression, purification, and hemolysis characteristics of this fusion protein were researched.

Methods: The SLO gene in this study was from S. pyogenes NZ131 and the pectate lyase gene from A. nidulans GR5. Escherichia coli BL21 (DE3) was used as expression host and pET-28a (+) plasmid as expression vector. $\mathrm{Ni}^{2+}$-nitrilotriacetate-agarose column was used for protein purification. The fusion protein activity was measured by monitoring hemolysis of sheep red blood cells.

Results: In shaking flask fermentation, the goal protein expression might be higher than $600 \mathrm{mg} / \mathrm{L}$ culture at $0.6 \mathrm{mM} \mathrm{IPTG}, 25^{\circ} \mathrm{C}$, and $200 \mathrm{rpm}$ for 36 hours, about 5 fold of what was previously reported. The purified PEL-SLO fusion protein had a specialty of $1 \times$ $10^{7} \mathrm{HU} / \mathrm{mg}$, about 10 fold of natural SLO. For sheep red blood cell, PEL-SLO fusion protein exhibited its optimal hemolysis level at $\mathrm{pH}$ 6.5 and $30-40^{\circ} \mathrm{C}$.
\end{abstract}

Conclusions: The research demonstrated that PEL might have promoted SLO expression and strengthened its activity.

Keywords: Pectate Lyase, Streptolysin O, Fusion Expression, Escherichia coli

\section{Background}

Cytolysin family is a single and highly homologous family and consists of species of 5 genera: Streptococcus, Bacillus, Clostridium, Listeria, and Arcanobacterium (17). Streptolysin O (SLO) from Streptococcus pyogenes is an oxygen-labile cholesterol-dependent cytolysin (2) and can oligomerize to form large pores (8-10) and cause the cytolysis of some eukaryotic cells, particularly erythrocytes (5) to bind to a cholesterol-containing membrane in the form of monomers. The produced pores allow the permeation of ions and small metabolites as well as macromolecules such as hemoglobin and immunoglobulin, with up to 100 $\mathrm{kDa}$ mass, to the cytosol (11).

The action for introducing proteins and nucleic acid into living cells has been found to have multifaceted applications in animal cell biology in humans or animals. With SLO, 3 active domains of large clostridial toxins (Clostridium difficile B-toxin, C. sordelli lethal toxin, and C. botulinum $\mathrm{C} 2$ toxin) were introduced into 3 different cell lines, and the results revealed that all the 3 toxins disrupted the actin cytoskeleton to cause the rounding up of the cells (7). A past study indicated that SLO treatment improved the cell fusion of fetal fibroblasts and the nucleic transferring of porcine embryo (12). Streptolysin O was used as an adjunct therapy with antibiotics to reduce the duration and severity of disease caused by Rhodococcus equipneumonia compared to antibiotic therapy alone (13). Adjunct therapy of SLO/antibiotics also reportedly modulated the sitespecific expression of extracellular matrix and inflammatory genes in lungs of R. equi infected foals (14).

Most commercially available SLO was natural SLO purified from S. pyogenes cultures (15). However, the purification of natural SLO has several drawbacks such as low yield, considerable batch-to-batch variation, and biological risk in industrial processes. Therefore, recombinant SLO is used as an alternative to avoid most of those drawbacks. A great deal of research has been conducted to express full SLO protein, full mature SLO protein, and mature SLO fragment deficient in the $\mathrm{N}$-terminal side.

The effects of different fusion tags of SLO expression in Escherichia coli was researched as follow. The recombinant mature SLO (containing 32 - 571 amino acids) fused with

Copyright (C) 2017, Jundishapur Journal of Microbiology. This is an open-access article distributed under the terms of the Creative Commons Attribution-NonCommercial 4.0 International License (http://creativecommons.org/licenses/by-nc/4.0/) which permits copy and redistribute the material just in noncommercial usages, provided the original work is properly cited. 
His-tag was expressed in E. coli, and the yield of the SLO fusion protein was $10-30 \mathrm{mg} / \mathrm{L}$ culture (16). Velazquez et al. expressed the fusion protein of SLO (78 - 571 acid amino sequence) with GST in E. coli, and its purified SLO yield was $1.5 \mathrm{mg} / \mathrm{L}$ culture (17). The recombinant mature SLO was expressed as another fusion protein with a thioredoxin and a C-terminal hexahistidine tag, and the yield of SLO fusion protein yield was $124 \mathrm{mg} / \mathrm{L}$ culture medium according to SLO activity concentration (2000 $\mathrm{HU} / \mathrm{mL}$ cell suspension) and specific activity (16102 U/mg) (18). To meet the increasing need of SLO in research and application in animal cell biology and medicine, a PEL-SLO fusion protein was highly expressed with a pectate lyase (PEL) as fusion tag (19), and its hemolysis activity was characterized.

\section{Objectives}

A fusion protein of pectate lyase and streptolysin $\mathrm{O}$ were highly expressed with a pectate lyase (PEL, from Aspergillus nidulans) as a fusion partner. The conditions of expression, purification, and hemolysis characteristics of this fusion protein were researched.

\section{Methods}

\subsection{Ethics Statement}

The main materials of the research included bacteria, sheep red blood cell, and bacteria plasmids. The project was reported to Yancheng Teachers University Ethics Committee and showed that no animals, plants, and population were inclusive in the study (Yancheng Teachers University ethics committee code: reference number 2014030503).

\subsection{Strain and Plasmids}

The streptolysin O gene (slo, NCBI GenBank accession number: NC-011375) was from S. pyogenes NZ131. The pectate lyase gene (pel, NCBI GenBank accession number: EF452421) was from A. nidulans GR5 (Fungal Genetics Stock Center, Kanasas, MO, USA) (16). Escherichia coli strain DH5 $\alpha$ (Lucigen, USA) was used as the clone host, and pMD18-T plasmid (TaKaRa, P.R. China) was employed as clone vector. Moreover, E. coli BL21 (DE3) (NEB, USA) was served as expression host and pET-28a (+) plasmid (Invitrogen, USA) was employed as expression vector. Sheep red blood cell (CELLBIO, China) was used to measure the hemolysis activity.
3.3. Designation of Amino Acid Sequence of Fusion Protein in Pectate Lyase and Streptolysin $O$

The amino acid sequence in fusion protein of pectate lyase and streptolysin O (PEL-SLO) is demonstrated in Figure 1 . The amino acids 1 - 313 were a pectate lyase (PEL) from the mycelium of A. nidulans (19).

\subsection{Cloning and Expression}

The slo fragment was amplified with PfuUltraTM HighFidelity DNA Polymerase (Stratagene, La Jolla, CA, USA), total genomic DNA from S. pyogenes NZ131, and sequence specific primers p1: '-CATATGGCTTGCTCCCAAAGAAATGC3' 2: 5'-GGATCCCTACTTATAAGTAATCGAACC-3') (Sangon Biontech, China) to construct slo/pMD18-T clone plasmid. The pel-ek-his DNA fragment was amplified with PfuUltraTM High-Fidelity DNA polymerase, pel/PMD18T (19), slo/pMD18-T and sequence specific primers p3: 5'-CCATGGGCTCACCTGCGCCGGACCTCAACG-3' p4: 5'-CATATG- GGTGATGATGATGATGATGATGATGATGATGCTTGTCGTCGTCGTCCAATTTCT-GTCCGGCTGTACCCGGAATCACG3') (Sangon Biontech, China) to construct pel-ek-his/pMD18T clone plasmid. Then, pel-ek-his-slo/pET-28a (+) was constructed and transformed into E. coli BL21 (DE3).

In Luria-Bertani (LB) with $1 \%(w / v)$ glucose and 50 $\mathrm{mg} / \mathrm{mL}$ kanamycin, the transformants were cultivated at $37^{\circ} \mathrm{C}$ and $200 \mathrm{rpm}$ to an absorbance (at $600 \mathrm{~nm}$ ) of 0.8. Then, culture broth was added with Isopropyl ß-D-1thiogalactopyranoside (IPTG) at $0.6 \mathrm{mM}$ final concentration. The mixture was grown at $25^{\circ} \mathrm{C}$ and $200 \mathrm{rpm}$ for another 36 hours for induction of recombinant protein synthesis.

\subsection{Sodium Dodecyl Sulfate Polyacrylamide Gel Electrophoresis}

Sodium dodecyl sulfate polyacrylamide gel electrophoresis (SDS-PAGE) was performed using $11.0 \%$ polyacrylamide gel (20).

\subsection{Extraction and Purification}

Cell intracellular protein was extracted and loaded on $\mathrm{a} \mathrm{Ni}^{2+}$-nitrilotriacetate-agarose column (Novagen, USA) to purify recombinant expressed PEL-SLO fusion protein according to the system manual. Eluted PEL-SLO was dialyzed against $10 \mathrm{mM}$ phosphate buffer ( $\mathrm{pH}$ 7.0), with a dialysis membrane (Sigma-Aldrich, USA). The amount of protein was measured using Bradford's method (21).

\subsection{Hemolysis Activity Assay}

Hemolysis activity of PEL-SLO was measured as described by Herbert $(22,23)$. 


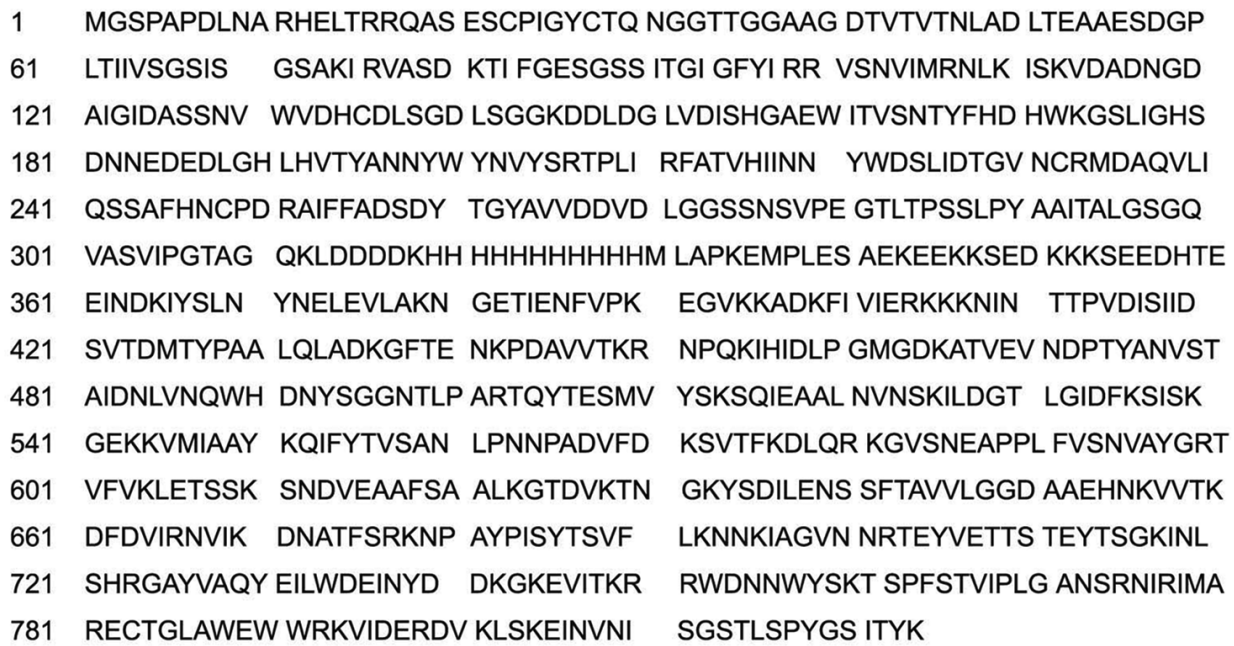

1, 1-313 amino acid, PEL; 2, 314 - 318 amino acid, EK; 3, 319 - 329 amino acid, His-tag; 4, 330 - 824 amino acid, SLO fragment, deficient in 77 residues on the N-terminal side of nature SLO.

\section{Results}

\subsection{Expression}

The recombinant PEL-SLO fusion protein was successfully overproduced (Figure 2). The recombinant SLO protein was also produced with E. coli BL21 (DE3) as the host for expression, and the pET-28a (+) plasmid as expression vector (Figure 2). After fully exploring the expression conditions, the best expression efficiency of soluble PEL-SLO fusion protein was found to be higher than $600 \mathrm{mg} / \mathrm{L}$ in shaking flask at $0.6 \mathrm{mM}$ IPTG (Figure $3 \mathrm{~A}$ ), $25^{\circ} \mathrm{C}$ (Figure $3 \mathrm{~B}$ ), and for 36 hours (Figure $3 \mathrm{C}$ ). The best expression efficiency of recombinant SLO (not using PEL as fusion partner) might be no more than $30 \mathrm{mg} / \mathrm{L}$ in shaking flask at $0.6 \mathrm{mM}$ IPTG, $25^{\circ} \mathrm{C}$, and for 36 hours (Figure 2 ).

\subsection{Purification of Recombinant Protein}

Figure 2 demonstrates the result of the purification of the PEL-SLO fusion protein. The predicted molecule weight of the SLO fusion protein was $91.7 \mathrm{Kd}$. The best purification conditions were the binding buffer $(10 \mathrm{mmol} / \mathrm{L}$ imidazole, $500 \mathrm{mmol} / \mathrm{L} \mathrm{NaCl}, 20 \mathrm{mmol} / \mathrm{L}$ Tris-HCl, pH 7.9), the washing buffer (60 mmol/L imidazole, $500 \mathrm{mmol} / \mathrm{L} \mathrm{NaCl}, 20 \mathrm{mmol} / \mathrm{L}$ Tris-HCl, pH 7.9), and 3 elution buffers (100, 200 and 500 $\mathrm{mmol} / \mathrm{L}$ imidazole, $500 \mathrm{mmol} / \mathrm{L} \mathrm{NaCl}, 20 \mathrm{mmol} / \mathrm{L}$ Tris-HCl, $\mathrm{pH}$ 7.9). When the concentration of $10 \mathrm{mmol} / \mathrm{L}$ imidazole in binding buffer was used, the most effective combination of fusion protein and $\mathrm{Ni}^{2+}$-nitrilotriacetate-agarose column was reached. The most impurities and little goal protein
Figure 2. Analysis of Expressed PEL-SLO and SLO Fusion Protein by SDS-PAGE

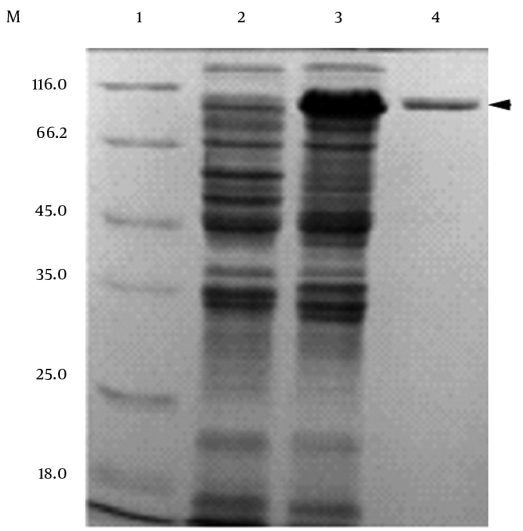

M: Protein marker; 1: supernatant sample from induced pET-28a (+)/BL21(DE3); 2: supernatant sample from induced pel-ek-his-slo/BL21(DE3); 3: purified the fusion protein of pectate lyase and Streptolysin $\mathrm{O}$ by $\mathrm{Ni}^{2+}$-nitrilotriacetate-agarose column (loading buffer with $10 \mathrm{mmol} / \mathrm{L}$ imidazole binding; binding buffer: with $10 \mathrm{mmol} / \mathrm{L}$ imidazole; washing buffer: with $60 \mathrm{mmol} / \mathrm{L}$ imidazole; eluting buffer: with $100-500$ mmol/L imidazole).

were washed when the $60 \mathrm{mmol} / \mathrm{L}$ imidazole concentration in washing buffer was used. Elution was applied by 3 steps with 3 elution buffers $(100 \mathrm{mmol} / \mathrm{L}$ imidazole, 500 $\mathrm{mmol} / \mathrm{L} \mathrm{NaCl}, 20 \mathrm{mmol} / \mathrm{L}$ Tris-HCl, pH 7.9; 200 mmol/L imidazole, $500 \mathrm{mmol} / \mathrm{L} \mathrm{NaCl}, 20$ mmol/L Tris-HCl, pH 7.9; 500 $\mathrm{mmol} / \mathrm{L}$ imidazole, $500 \mathrm{mmol} / \mathrm{L} \mathrm{NaCl}, 20 \mathrm{mmol} / \mathrm{L}$ Tris-HCl, 
Figure 3. The Expression Conditions of PEL-SLO Fusion Protein in E. coli

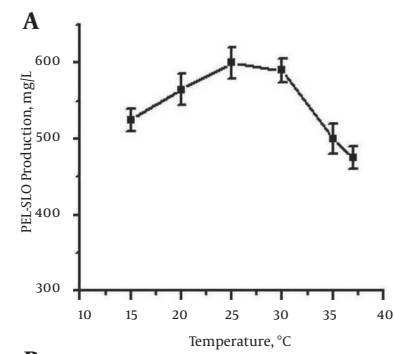

B

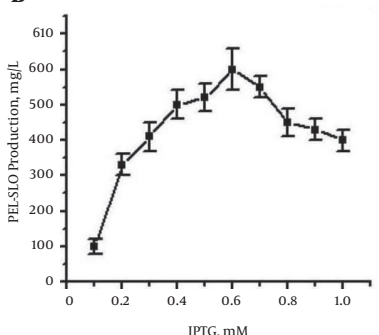

C

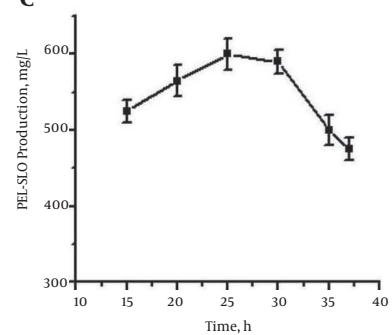

Cells of pel-ek-his-slo/pET-28a (+)/E. coli BL21 (DE3) were incubated at $37^{\circ} \mathrm{C}$ at 200 $\mathrm{rev} / \mathrm{min}$ to the cell density with OD600 about 0.8 , and then placed under different conditions for expression of PEL-SLO.(A) At different temperatures $\left(15-37^{\circ} \mathrm{C}\right)$, expressions were performed under the induction of $0.6 \mathrm{mM} \mathrm{IPTG}$ at $200 \mathrm{rev} / \mathrm{min}$ for 36 hours; (B) expressions were induced by different concentrations of IPTG (0.05- 1.0 $\mathrm{mM}$ ) at $25^{\circ} \mathrm{C}$ and $200 \mathrm{rev} / \mathrm{min}$ for 36 hours; (C) expressions were performed at $25^{\circ} \mathrm{C}$ at $200 \mathrm{rev} / \mathrm{min}$ under the induction of $0.6 \mathrm{mM}$ IPTG for different lengths of time.

$\mathrm{pH} 7.9)$.

\subsection{Hemolysis Characterization of the PEL-SLO Fusion Protein}

The molecular mass of the recombinant PEL-SLO fusion protein was about $91.7 \mathrm{kDa}$, determined by SDS-PAGE (Figure 2), which was identical to the prediction with Dnaman soft (http://www.lynnon.com). The calculated pI of the recombinant fusion protein was 5.39. For sheep red cells, the optimum reaction conditions for the recombinant fusion PEL-SLO protein activity were $30-40^{\circ} \mathrm{C}$ (Figure $4 \mathrm{~A}$ ) and $\mathrm{pH}$ 6.5 (Figure 4B). Temperature stability test revealed that SLO fusion protein exhibited $80 \%$ approximate activity at 0 $30^{\circ} \mathrm{C}$ and $\mathrm{pH} 7.0$ for 1 hour (Figure $4 \mathrm{C}$ ), whereas $\mathrm{pH}$ stability test revealed that the fusion protein retained about $80 \%$ activity over the range of $\mathrm{pH} 5.0$ - 11 at the most stable temperature for 1 hour (Figure 4D). The hemolysis activity test showed that the specialty of the purified new SLO fusion protein reached $1 \times 10^{7} \mathrm{HU} / \mathrm{mg}$.

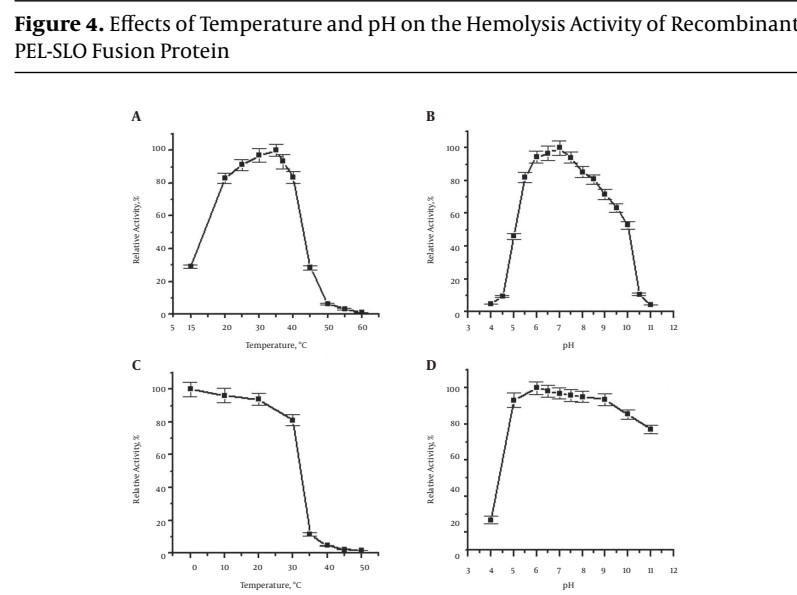

A, Temperature dependence of the hemolysis activity; $\mathrm{B}, \mathrm{pH}$ dependence of the hemolysis activity; $\mathrm{C}$, thermo stability of the fusion protein; $\mathrm{D}, \mathrm{pH}$ stability of the fusion protein. The highest hemolysis activity was designated as $100 \%$ in experiments of $\mathrm{pH}$ and temperature dependence. The activity of the toxin without preincubation was designated as $100 \%$ in experiments of temperature and pH stability.

\section{Discussion}

\subsection{The Reason of PEL Promoting the SLO Biosynthesis}

The yield of the SLO fusion protein was $600 \mathrm{mg} / \mathrm{L}$ culture, and the yield of purified SLO fusion protein was 100 $\mathrm{mg} / \mathrm{L}$ culture. This yield was about 5 fold of what was previously reported $(17,18)$. The recombinant mature SLO (containing 32 - 571 amino acids) fused with His-tag was expressed in E. coli, and the yield of the SLO fusion protein was 10 - $30 \mathrm{mg} / \mathrm{L}$ culture (16). Velazquez et al. (17) expressed the fusion protein of SLO (78 - 571 acid amino sequence) with GST in E. coli, and its purified SLO yield was $1.5 \mathrm{mg} / \mathrm{L}$. The recombinant mature SLO was expressed as another fusion protein with a thioredoxin and a C-terminal hexahistidine tag, and the yield of SLO fusion protein yield was $124 \mathrm{mg} / \mathrm{L}$ medium according to SLO activity concentration (2000 HU/mL cell suspension) and specific activity (16102 $\mathrm{U} / \mathrm{mg}$ ) (15). The reason for PEL promoting the SLO biosynthesis might be reduction in the SLO's physiological toxicity and the growth inhibition effect on E. coli (data not published).

5.2. The Pectate Lyase Could Strengthen the Hemolysis Activity of SLO

Specific hemolysis activity of purified PEL-SLO was $1 \times$ $10^{7} \mathrm{IU} / \mathrm{mg}$, which was higher than that of native SLO (32 571 amino acid sequence) and was about 10 fold of native 
SLO. Specific hemolysis activity of purified native SLO has been reported as $8 \times 10^{5} \mathrm{HU} / \mathrm{mg}$ of protein (4). A similar level was also published for recombinant SLO (32 - 571 amino acid sequence) (22). The mature SLO (contain 32 - 571 amino acid) fused with His-tag had a specific activity $(748,000 \mathrm{HU} / \mathrm{mg}$ protein) and its activity was identical to mature natural or recombinant SLO (16). Our result revealed that PEL fusion tag could strengthen the activity of SLO, and this result was identical to the SLO fusion protein (78 - 571 acid amino sequence) with GST, which had a specific hemolysis activity of $1 \times 10^{8} \mathrm{HU} / \mathrm{mg}$ (17). Thioredoxin was also used as SLO fusion tag, but the effect of thioredoxin on SLO activity was different from PEL and GST, and its specific activity was only $16102 \mathrm{HU} / \mathrm{mg}$ (18).

\subsection{Effect of Pectate Lyase on the Antigenicity of Streptolysin $O$}

In the study, recombinant SLO had antigenicity, but recombinant PEL-SLO did not show antigenicity (not published). The antigenicity of proteins was determined by antigenic determinants and the antigenic determinants of the proteins had 2 types of sequential epitope $(24,25)$ and conformation epitope (26). The research showed that the purified PEL-SLO fusion protein had a specialty of $1 \times 10^{7}$ $\mathrm{HU} / \mathrm{mg}$, about 10 fold of natural SLO. Thus, the conformation of PEL-SLO should be right; the effect of pectate lyase on the antigenicity of SLO should belong to the steric effect resulting from pectate lyase although no researches showed SLO had any sequential epitope or conformation epitope. In this study, the pectate lyase was attached to the N-end of SLO fragment, so the antigenic determinant of SLO might be near the N-end of SLO fragment. Conformation epitope might be more easily affected by steric than sequential epitope (27), and the epitope of SLO might be conformation epitope (28-30).

\subsection{Conclusion}

The yield of the fusion protein of PEL-SLO in E. coli was $600 \mathrm{mg} / \mathrm{L}$ culture, and the yield was about 5 fold of the previously reported yield. Specific hemolysis activity of purified PEL-SLO was $1 \times 10^{7} \mathrm{IU} / \mathrm{mg}$, which was higher than that of native SLO (32 - 571 amino acid sequence) and was about 10 fold of native SLO. The PEL-SLO fusion protein could meet the increasing need of SLO applications better in animal cell biology and medicine science.

\section{Acknowledgments}

This work was financially supported by the funds from Jiangsu Key Laboratory for Bioresources of Saline Solis. The project was approved by Yancheng teachers University ethics committee (reference number: 2014030503).

\section{References}

1. Abe Y, Alouf JE, Kurihara T, Kawashima H. Species-dependent response to streptococcal lymphocyte mitogens in rabbits, guinea pigs, and mice. Infect Immun. 1980;29(2):814-8. [PubMed: 7011987].

2. Alouf JE. Streptococcal toxins (streptolysin O, streptolysin S, erythrogenic toxin). Pharmacol Ther. 1980;11(3):661-717. [PubMed: 7003609].

3. Alouf JE. Cholesterol-binding cytolytic protein toxins. Int J Med Microbiol. 2000;290(4-5):351-6. doi: 10.1016/S1438-4221(00)80039-9. [PubMed: 11111910].

4. Bhakdi S, Tranum-Jensen J, Sziegoleit A. Mechanism of membrane damage by streptolysin-O. Infect Immun. 1985;47(1):52-60. [PubMed: 3880730].

5. Billington SJ, Jost BH, Songer JG. Thiol-activated cytolysins: structure, function and role in pathogenesis. FEMS Microbiol Lett. 2000;182(2):197-205. doi: 10.1016/S0378-1097(99)00536-4. [PubMed: 10620666].

6. Feil SC, Ascher DB, Kuiper MJ, Tweten RK, Parker MW. Structural studies of Streptococcus pyogenes streptolysin O provide insights into the early steps of membrane penetration. J Mol Biol. 2014;426(4):785-92. doi: 10.1016/j.jmb.2013.11.020. [PubMed: 24316049].

7. Gupta RK. Antibody response to streptolysin O in mammals. J Infect Dis. 1980;142(4):624. [PubMed: 7441021].

8. O'Seaghdha M, Wessels MR. Streptolysin O and its co-toxin NADglycohydrolase protect group A Streptococcus from Xenophagic killing. PLoS Pathog. 2013;9(6):e1003394. doi: 10.1371/journal.ppat.1003394. [PubMed: 23762025].

9. Palmer M. The family of thiol-activated, cholesterol-binding cytolysins. Toxicon. 2001;39(11):1681-9. [PubMed: 11595631].

10. Walker MJ, Barnett TC, McArthur JD, Cole JN, Gillen CM, Henning ham A, et al. Disease manifestations and pathogenic mechanisms of Group A Streptococcus. Clin Microbiol Rev. 2014;27(2):264-301. doi: 10.1128/CMR.00101-13. [PubMed: 24696436].

11. Walev I, Bhakdi SC, Hofmann F, Djonder N, Valeva A, Aktories K, et al. Delivery of proteins into living cells by reversible membrane permeabilization with streptolysin-O. Proc Natl Acad Sci U S A. 2001;98(6):3185-90. doi:10.1073/pnas.051429498. [PubMed: 11248053].

12. Naruse K, Quan YS, Kim BC, Choi SM, Park CS, Jin DI. Streptolysino treatment of fetal fibroblasts improves cell fusion and in vitro development of porcine nuclear transfer embryos. J Reprod Dev. 2009;55(3):236-9. [PubMed: 19202321].

13. Horohov DW, Loynachan AT, Page AE, Hughes K, Timoney JF, Fettinger $\mathrm{M}$, et al. The use of streptolysin O (SLO) as an adjunct therapy for Rhodococcus equi pneumonia in foals. Vet Microbiol. 2011;154(1-2):15662. doi: 10.1016/j.vetmic.2011.06.037. [PubMed: 21798675].

14. Gurel V, Lambert K, Page AE, Loynachan AT, Huges K, Timoney JF, et al. Streptolysin-O/antibiotics adjunct therapy modulates site-specific expression of extracellular matrix and inflammatory genes in lungs of Rhodococcus equi infected foals. Vet Res Commun. 2013;37(2):14554. doi: 10.1007/s11259-013-9557-y. [PubMed: 23475766].

15. Kimoto H, Fujii Y, Hirano S, Yokota Y, Taketo A. Expression of recombinant Streptolysin $\mathrm{O}$ and specific antibody production. J Mol Microbiol Biotechnol. 2005;10(1):64-8. doi: 10.1159/000090349. [PubMed: 16491027].

16. Fiorentini GP, Volpe G. [Determination of anti-streptolysin O antibodies, using micromethods]. Quad Sclavo Diagn. 1980;16(1):25-9. [PubMed: 6972545].

17. Velazquez B, Massaldi H, Battistoni J, Chabalgoity JA. Construction and expression of recombinant streptolysin-o and preevaluation of its use in immunoassays. Clin Diagn Lab Immunol. 2005;12(5):683-4. doi: 10.1128/CDLI.12.5.683-684.2005. [PubMed: 15879035].

18. Camprubi S, Bruguera M, Canalias F. Purification of recombinant histidine-tag streptolysin $\mathrm{O}$ using immobilized metal affinity expanded bed adsorption (IMA-EBA). Int J Biol Macromol. 2006;38(2):1349. doi: 10.1016/j.ijbiomac.2006.02.005. [PubMed:16529807]. 
19. Zhao Q, Yuan S, Wang X, Zhang Y, Zhu H, Lu C. Restoration of mature etiolated cucumber hypocotyl cell wall susceptibility to expansin by pretreatment with fungal pectinases and EGTA in vitro. Plant Physiol. 2008;147(4):1874-85. doi:10.1104/pp.108.116962. [PubMed: 18562768].

20. Chevallet $M$, Luche $S$, Rabilloud T. Silver staining of proteins in polyacrylamide gels. Nat Protoc. 2006;1(4):1852-8. doi: 10.1038/nprot.2006.288. [PubMed: 17487168].

21. Bradford MM. A rapid and sensitive method for the quantitation of microgram quantities of protein utilizing the principle of protein-dye binding. Anal Biochem. 1976;72:248-54. doi: 10.1016/00032697(76)90527-3. [PubMed: 942051].

22. Herbert D, Todd EW. Purification and properties of a haemolysin produced by group A haemolytic streptococci (streptolysin O). Biochem J. 1941;35(10-11):1124-39. [PubMed:16747398].

23. Pinkney M, Kapur V, Smith J, Weller U, Palmer M, Glanville M, et al. Different forms of streptolysin O produced by Streptococcus pyogenes and by Escherichia coli expressing recombinant toxin: cleavage by streptococcal cysteine protease. Infect Immun. 1995;63(7):27769. [PubMed: 7790099].

24. Kogo H, Shimizu M, Negishi Y, Uchida E, Takahashi H. Suppression of murine tumour growth through CD8+ cytotoxic T lymphocytes via activated DEC-205+ dendritic cells by sequential administration of alpha-galactosylceramide in vivo. Immunology. 2017;151(3):324-39. doi:10.1111/imm.12733. [PubMed: 28294313].
25. Wang S. Optimal Sequential Immunization Can Focus Antibody Responses against Diversity Loss and Distraction. PLoS Comput Biol. 2017;13(1):e1005336. doi: 10.1371/journal.pcbi.1005336. [PubMed: 28135270].

26. Agadjanyan MG, Zagorski K, Petrushina I, Davtyan H, Kazarian K, Antonenko $\mathrm{M}$, et al. Humanized monoclonal antibody armanezumab specific to N-terminus of pathological tau: characterization and therapeutic potency. Mol Neurodegener. 2017;12(1):33. doi: 10.1186/s13024017-0172-1. [PubMed: 28472993].

27. Najar TA, Khare S, Pandey R, Gupta SK, Varadarajan R. Mapping Protein Binding Sites and Conformational Epitopes Using Cysteine Labeling and Yeast Surface Display. Structure. 2017;25(3):395-406. doi: 10.1016/j.str.2016.12.016. [PubMed: 28132782].

28. Cunningham MW. Pathogenesis of group A streptococcal infections. Clin Microbiol Rev. 2000;13(3):470-511. doi: 10.1128/CMR.13.3.470511.2000. [PubMed: 10885988].

29. Chiarot E, Faralla C, Chiappini N, Tuscano G, Falugi F, Gambellini G, et al. Targeted amino acid substitutions impair streptolysin O toxicity and group A Streptococcus virulence. MBio. 2013;4(1):e00387-12. doi: 10.1128/mBio.00387-12. [PubMed: 23300245].

30. Johnson S, Brooks NJ, Smith RA, Lea SM, Bubeck D. Structural basis for recognition of the pore-forming toxin intermedilysin by human complement receptor CD59. Cell Rep. 2013;3(5):1369-77. doi: 10.1016/j.celrep.2013.04.029. [PubMed: 23665225]. 